\title{
The European Union's Energy Security Challenges
}

\section{Paul Belkin *}

\section{Abstract}

Recent increases in energy prices and a steady escalation in global energy demand-expected to rise by nearly 60 percent over the next twenty years - have led U.S. policymakers to engage in a wide-ranging debate over how best to address the country's future energy requirements. Similarly, energy security has become a policy priority for the European Union (EU) and its twenty-seven member states. Together, the United States and Europe represent the world's largest energy market. Although they produce approximately 23 percent of the world's energy, they consume almost 40 percent of the world's supply.

The EU imports about 50 percent of the energy that it consumes. Barring significant changes, the European Commission expects this figure to rise to 65 percent by 2030. Approximately half of the EU's imported energy comes from Russia, in the form of oil and natural gas. Europe's growing dependence on Russian energy has fueled speculation that Moscow is using the "energy weapon" to try to influence European foreign and economic policy.

The EU has traditionally exerted little if any influence over the energy policies of its individual member states. However, in March 2007, in the face of increasing concern regarding Europe's reliance on Russian energy resources, and growing public pressure to address global climate change, the EU member states agreed on a series of policy measures intended to form the foundation of an "Energy Policy for Europe." The March agreement aims to increase the EU's ability to secure and diversify European energy supplies, while seeking to reduce EU-wide carbon emissions by promoting alternative and renewable energy sources.

The United States and Europe have steadily broadened the transatlantic energy dialogue to include joint promotion of collective energy security, energy efficiency, and alternative energy sources. Leaders on both sides of the Atlantic have agreed to pursue U.S.-EU cooperation to develop alternative and renewable energy technologies and to forge coordinated policies with regard to Russia and politically unstable regions with substantial energy resources. U.S. officials have expressed some concern at some European member states' unwillingness to exert more pressure on Russia to comply with EU market principles. On the other hand, European leaders appear increasingly frustrated with U.S. resistance to binding multilateral regulatory frameworks to reduce carbon emissions and promote energy efficiency.

This article examines some of Europe's critical energy security challenges and EU efforts to coordinate a common European energy strategy. It also includes an overview of broader transatlantic energy security cooperation. ${ }^{1}$

Paul Belkin is an Analyst in European Affairs in the Foreign Affairs, Defense, and Trade Division of the Congressional Research Service in Washington, D.C. A version of this article was published by the CRS on 7 May 2007. 


\section{Introduction}

Although the European Union's (EU) twenty-seven member states have ceded some national sovereignty (or competency) to EU institutions in a variety of areas, including economic and trade policy, energy policy remains primarily the responsibility of the individual member states. Decisions regarding long-term oil or gas purchases, the development and improvement of energy-related infrastructure, and the use of particular fuels continue to be made at the national level by EU member states.

At their March 2007 summit, the member states of the EU moved to boost European coordination to help secure and diversify energy supplies, increase the development and use of renewable and alternative energy resources within the EU, and reduce energy demand and consumption. Although member state governments remain reluctant to cede national sovereignty over aspects of their foreign policies related to energy security, they have set binding EU-wide targets for the use of renewable energies and biofuels, and have agreed to ambitious but non-binding energy efficiency and carbon emission reduction targets for the year 2020. In addition, member states are considering potentially significant reforms to further liberalize the European energy market. Nonetheless, most observers expect member states to continue to retain significant national control over their energy markets and their external relations with energy-producing countries.

Europe's renewed interest in energy security has been influenced by both internal and external factors. Internally, steadily rising energy prices, declining European energy production, and a fragmented internal energy market have contributed to anxieties over Europe's ability to meet future demands for energy. Externally, the strain on global demand exerted by the emerging economies of countries such as China and India, persistent instability in energy producing regions, the threat of terrorist strikes against energy infrastructure, and Russia's apparent willingness to use its energy power for political ends are all raising concerns in Europe over how to address external influences that could affect future energy requirements. ${ }^{2}$ Recent calls for EU-wide energy coordination have been driven by rising European concern about the effects of energy production and consumption on global climate change. To this end, EU member states' recent energy policy decisions center largely on promoting energy efficiency, developing renewable energy and clean fuel sources, and reducing overall greenhouse gas emissions.

As uncertainties surrounding global energy supply and demand persist, issues pertaining to U.S., European, and global energy security are likely to gain importance on the U.S. political scene. Members of both the Democratic and Republican parties have introduced legislation aimed at increasing energy independence and energy security and reducing car-

An initial version of this report was written by former CRS Analyst Vince L. Morelli. For additional information, see Robert Pirog and Bernard Gelb, Russian Oil and Gas Challenges, CRS Report RL33212 (Washington, D.C: Congressional Research Service, updated June 2007); available at www.fas.org/sgp/crs/row/RL33212.pdf. See also Paul Gallis, NATO and Energy Security, CRS Report RS22409 (Washington, D.C.: Congressional Research Service, updated August 2007); available at http://italy.usembassy.gov/pdf/other/RS22409.pdf.

2 Jos Van Gennip, Energy Security, NATO Parliamentary Assembly paper, No. 170 ESC 06 E (2006); available at www.nato-pa.int/Default.asp?CAT2 $=982 \& \mathrm{CAT} 1=16 \& \mathrm{CAT} 0=2 \& \mathrm{COM}=$ $1000 \& \mathrm{MOD}=0 \& \mathrm{SMD}=0 \& \mathrm{SSMD}=0 \& \mathrm{STA}=\& \mathrm{ID}=0 \& \mathrm{PAR}=0 \& \mathrm{PRINT}=1$. 
bon emissions. Several of these proposals envision carbon-trading schemes similar to those in use in Europe. ${ }^{3}$ On 12 April 2007, the U.S. Senate Foreign Relations Committee reported out the Energy Diplomacy and Security Act (S. 193), which would require the Administration to enhance its efforts to foster international cooperation on energy issues. The bill's sponsor, Senator Richard Lugar, also raised the possibility of a more proactive role for NATO in energy security matters at NATO's summit in Riga, Latvia in November 2006.

\section{The Context of Europe's Energy Security Debate}

\section{Background}

Collectively, EU member states import half of the energy that they consume. Barring significant policy changes, this figure is expected to rise to 65 percent by $2030 .{ }^{4}$ Today, oil, natural gas, and coal account for 80 percent of the energy consumed in the EU.

Europe's energy imports come primarily from Russia and the Middle East, where approximately 70 percent of global oil and gas supplies originate. Yet the Middle East as a region is fraught with war, terrorism, and politically unstable regimes. Iraq's oil production has not yet reached pre-war levels, and there is fear that terrorist groups could target pipelines and production facilities throughout the region. Iran has threatened to cut back oil production if forced to abandon its nuclear power program. With regard to Russia, recent political and economic behavior exhibited by Moscow has raised the dual specter of reliability and "energy politics."

High demand has also raised questions regarding the future availability of global oil and gas reserves. Although significant shortages are not projected for the next several decades, uncertainties over future exploration and production in areas such as Russia and the Middle East have raised concerns about long-term supply availability. The International Energy Agency (IEA) estimates that close to USD 16 trillion in new investments may be needed over the next thirty years to meet future global energy demand. ${ }^{5}$

European concern regarding the security of its energy supply was first prompted by the Arab oil embargo of the early 1970s. Specifically, the embargo highlighted three main issues. First, it exposed a need for increased energy policy collaboration among European countries and between Europe and the energy-producing world. Second, it became clear that institutional mechanisms for increased coordination in the event of future supply disruptions were essential. Third, consensus emerged that Europe should prepare strategies to

3 For more information on the EU's carbon emission trading system see, Larry Parker, Climate Change: The European Union's Emissions Trading System (EU-ETS), CRS Report RL33581 (Washington, D.C.: Congressional Research Service, July 2006); available at www.usembassy.at/ en/download/pdf/eu_ets.pdf.

4 See "Energy Overview," Council of the European Commission, June 2006; Commission of the European Communities, "An Energy Policy for Europe," Communication from the Commission to the European Council and the European Parliament, Doc. No. COM(2007) 1 (10 January 2007); available at http://ec.europa.eu/energy/energy_policy/doc/01_energy_policy_for_europe_ en.pdf.

5 See International Energy Agency (IEA), World Energy Investment Outlook (2005); available at www.worldenergyoutlook.org/2005.asp. 
prevent it from becoming the victim of future attempts by exporting nations to use energy as a political or economic weapon. ${ }^{6}$ The 1974 creation of the International Energy Agency (IEA), which has become Europe's primary instrument for monitoring and analyzing world energy markets, was one response to the embargo. In addition, European countries sought to develop strategies to diversify their energy supply.

After the embargo, European countries began to identify Russia and other Eurasian countries as potential energy suppliers. At the time, Soviet Russia was beginning to realize its energy producing potential, but it required major investments in its energy sector. The prospect of future cooperation in the energy field began to play a key role in European perspectives on developing relations with the Soviet Union.

In 1991, the European Union launched the Energy Charter Declaration, an initiative intended to promote energy cooperation and diversify Europe's energy supply. The Declaration gave way to the 1994 Energy Charter Treaty, which entered into legal force in 1998 and established a framework of rules and agreements to promote international energy cooperation. ${ }^{7}$ To date, fifty-one countries and the EU have signed or acceded to the Treaty. ${ }^{8}$ The Treaty seeks to create a level playing field of rules regarding the promotion of foreign energy investments. In addition, it provides mechanisms for dispute resolution, and promotes free trade in energy materials, products, and equipment; freedom of energy transit through pipelines and grids; and energy efficiency. ${ }^{9}$

Since the signing of the Energy Charter Treaty, the European Commission has used its existing competencies in competition and environment and consumer protection policy to attempt to shape a European energy policy in a variety of ways. ${ }^{10}$ These include promoting an internal gas and electricity market, encouraging the development of alternative energy supplies, and, in cooperation with the office of the High Representative for Common Foreign and Security Policy, pursuing a more cooperative approach to external relations with current and future energy suppliers.

\section{Turning Point}

A 2005 German-Russian gas pipeline agreement and more recent Russian manipulation of gas and oil flows to the European market have sparked a newfound sense of urgency

6 Daniel Yergin, "Ensuring Energy Security," Foreign Affairs (March/April 2006).

7 For more detailed information on the Treaty, see The Energy Charter Organization, The Energy Charter Treaty: A Reader's Guide (Brussels: Energy Charter Secretariat, January 2002); available at www.encharter.org/fileadmin/user upload/document/document1158668628.pdf.

8 Although the United States signed the 1991 Energy Charter Declaration, it has not signed the Energy Charter Treaty, so it retains the status of observer to the Charter process. U.S. officials have cited a preference to pursue energy-related matters on a bilateral basis.

9 The Energy Charter Treaty: A Reader's Guide.

10 The European Commission is the EU's executive and holds the sole right of legislative initiative. However, in many policy-making areas, the Commission remains primarily an administrative body serving the representatives of national governments, which make up the EU's main decision-making body, the Council of Ministers. For more information see Kristin Archick, The European Union: Questions and Answers, CRS Report RS21372 (Washington, D.C.: Congressional Research Service, updated April 2006); available at http://fpc.state.gov/documents/ organization/66459.pdf. 
among European leaders regarding the need for a more coordinated energy strategy. These events correspond with growing concern among the European public and political classes regarding the link between energy production and consumption and global climate change.

In 2005, Germany and Russia agreed to build a gas pipeline connecting the countries under the Baltic Sea. While Germany maintains that the pipeline will significantly enhance German and therefore European energy supply and security, a number of EU member states, including Poland and Lithuania, have protested the decision. They counter that, by running the pipeline under sea so it bypasses both countries, and by failing to coordinate with EU neighbors when negotiating with Russia, Germany's actions pose a threat to their individual and broader European energy security. ${ }^{11}$ Furthermore, prominent Swedish officials have voiced concerns that the pipeline will provide Russia with a platform to increase both military surveillance and its military presence in the strategically important Baltic Sea. ${ }^{12}$ The German-Russian agreement and subsequent responses from Poland, Lithuania, and more recently, Sweden, have reignited calls for a more coordinated European energy strategy.

As internal strife over the German pipeline decision continues, disputes pitting Russia against Ukraine and Belarus have exposed the undesirable consequences of European dependence on Russian energy resources. In late December 2005, Russia's gas monopoly, Gazprom, temporarily suspended gas flows to Ukraine as part of a dispute over gas price increases. Within hours of the shutoff, several European countries, including Austria, Italy, Poland, and Germany, reported drops in their own pipeline pressure by as much as 30 percent. ${ }^{13}$ The gas crisis lasted only a few days, and after Russia and Ukraine reached an agreement on gas prices, gas was flowing normally again.

An almost identical dispute between Russia and Belarus with similar consequences for European countries, particularly Germany, occurred in early January 2007. This time, Russian oil pipeline operator Transneft shut down the Druzhba oil pipeline through which Germany receives 20 percent of its oil imports. Germany and the EU sharply rebuked Russia's decision, and Russia resumed oil delivery after three days of price negotiations with Belarus.

Many European observers have characterized the Russia-Ukraine and Russia-Belarus gas and oil crises as "wake-up calls" that exposed Europe's energy security vulnerability, even to unintended supply disruptions. More importantly, however, the crises raised the dual questions of Russia's reliability as an energy partner and Moscow's willingness to use its energy power as a political weapon. In response, European leaders have sought to forge EU-wide policies to secure and diversify energy supply by better coordinating energy-re-

11 “Polish Press Slams Germany's Schroeder over Gas Pipeline Deal," Agence France-Presse (12 December 2005).

12 Alex Bakst, "Baltic Sea Pipeline: Sweden Afraid of Russian Spooks," Spiegel Online (15 November 2006); available at www.spiegel.de/international/0,1518,448652,00.html.

13 See "Q\&A: Ukraine Gas Row," BBC News (4 January 2006); and Jim Nichol, Steven Woehrel, and Bernard A. Gelb, Russia's Cutoff of Natural Gas to Ukraine: Context and Implications, CRS Report RS22378 (Washington, D.C.: Congressional Research Service, February 2006); available at http://italy.usembassy.gov/pdf/other/RS22378.pdf. 
lated decisions so as to present a unified front to producer nations like Russia and to promote alternative energy sources and more efficient energy use.

\section{European Energy Consumption: By the Numbers}

The EU's twenty-seven member states account for approximately 17 percent of the world's total energy consumption. ${ }^{14}$ In 2005 , about 80 percent of the energy consumed within the EU was from fossil fuels. Figure 1 provides an overview of the EU's energy consumption by fuel source.

Europe imports about 50 percent of its total energy supply-slightly over 80 percent of its oil, and close to 55 percent of its natural gas. Its dependence on imported energy sources, particularly natural gas, is expected to grow substantially in the coming decades. European Commission estimates suggest that, if current trends continue, Europe will import 65 percent of its total energy requirements by $2030 .{ }^{15}$ Russia, Norway, the Middle East, and North Africa are the largest suppliers of EU energy. In 2004, Russia accounted for 26 percent of the EU's oil imports, and 29 percent of natural gas imports. ${ }^{16}$

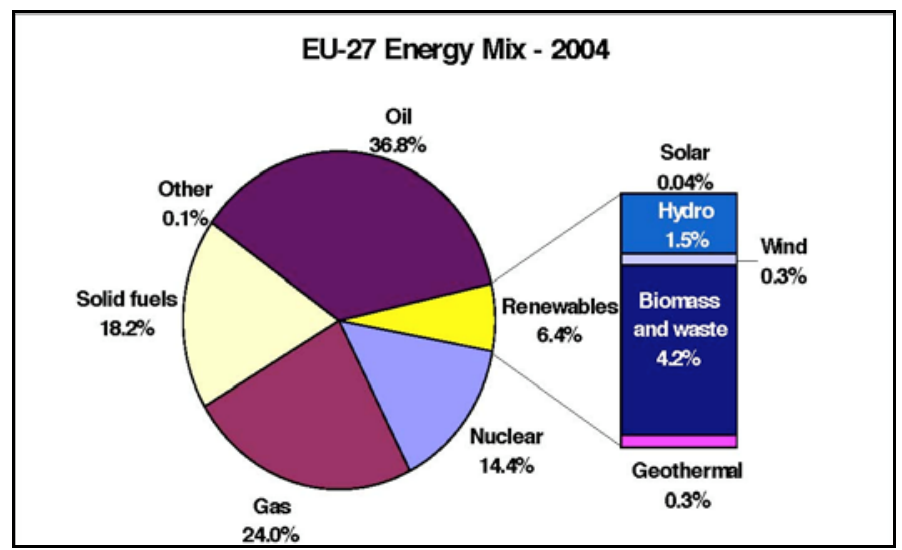

Figure 1: EU Energy Consumption ${ }^{17}$

Forecasters predict that natural gas consumption in the EU will double over the next twenty-five years, as gas has rapidly become Europe's fuel of choice for power generation. European natural gas consumption currently represents 18 percent of world consumption.

${ }^{14}$ Energy Information Administration, "Country Analysis Briefs: European Union," U.S. Department of Energy (January 2006); available at http://www.eia.doe.gov/cabs/European_Union/ Background.html.

15 "An Energy Policy for Europe," op. cit.

16 "EU Energy Policy Data," European Commission Document SEC(2007)12, (10 January 2007); The European Commission's Directorate-General of Energy and Transport, Statistical Pocket Book 2006; available at http://ec.europa.eu/dgs/energy_transport/figures/pocketbook/2006_en.htm.

17 European Commission DG TREN, Eurostat; European Commission Staff Working Document SEC(2007)12. 
By 2030, Europe is expected to import over 80 percent of its natural gas needs. ${ }^{18}$ Today, EU member states and Norway account for just over half of the EU's natural gas supply. The other half is imported primarily from Russia (29 percent) and Algeria (13 percent). Several EU member states are totally dependent on Russian natural gas for their domestic energy consumption. Table 1 illustrates the levels of dependency on Russian natural gas in selected nations of the EU.

Table 1: Imported Gas and Gas from Russia ${ }^{19}$

\begin{tabular}{lcc}
\hline Country & $\begin{array}{c}\text { Dependence on Imported } \\
\text { Gas, 2005 }\end{array}$ & $\begin{array}{c}\text { Total of Gas Consumption } \\
\text { Imported from Russia }\end{array}$ \\
\hline Austria & $88 \%$ & $74 \%$ \\
\hline Czech Republic & $98 \%$ & $70 \%$ \\
\hline Estonia & $100 \%$ & $100 \%$ \\
\hline France & $98 \%$ & $26 \%$ \\
\hline Finland & $100 \%$ & $100 \%$ \\
\hline Germany & $81 \%$ & $39 \%$ \\
\hline Italy & $85 \%$ & $30 \%$ \\
\hline Poland & $70 \%$ & $50 \%$ \\
\hline
\end{tabular}

\section{An Energy Policy for Europe?}

The Russia-Ukraine and Russia-Belarus oil and gas crises have corresponded with increasing public calls for concerted European action on climate change, spurring European leaders to renew efforts to establish a more cohesive European energy policy. During their March 2007 summit, EU heads of state adopted a series of European Commission proposals that they expect will form the foundation of an "Energy Policy for Europe." The adopted measures are among a larger group of recommendations the Commission laid out in a March 2006 "Green Paper" and a more detailed action plan unveiled in January 2007. ${ }^{20}$ The Commission proposals focus on three broad interconnected goals: increasing European-wide energy security; enhancing sustainability; and fostering competition in Europe's internal energy market. Commission officials place particular emphasis on the links between energy security, energy efficiency, and an EU-wide reduction in carbon emissions.

18 Ibid.

19 International Energy Agency; Eurostat; British Petroleum.

20 Both the Commission's Green Paper and a more detailed action plan are available at http://ec.europa.eu/energy/energy_policy/index_en.htm. 
In what some consider a reflection of both increasing public pressure to address global climate change and continued member state reluctance to cede national economic and foreign policy making authority, the EU's March 2007 agreement focused largely on Commission recommendations on sustainability. Member states did commit to take some steps toward further liberalizing the EU-wide energy market and have broadly endorsed increased foreign policy coordination on securing energy supplies. However, the EU's most far-reaching commitments focus on increasing energy efficiency, decreasing greenhouse gas emissions, and promoting the use of renewable energy and alternative fuels and associated technologies.

Specifically, EU member states have committed to reducing total EU-wide carbon emissions by 20 percent compared with 1990 levels by 2020. They have also pledged to seek international agreement on a 30 percent reduction target by 2020 in a post-Kyoto Protocol international carbon emissions reduction treaty. ${ }^{21}$ In addition, the EU seeks a 20 percent increase in Europe-wide energy efficiency by 2020, and has mandated that 20 percent of all EU energy consumption come from renewable sources and 10 percent of transport fuel from biofuels by 2020. Member states are expected to agree on country-specific targets to achieve these Europe-wide goals by late 2007.

According to a March 2007 study by the global consulting firm McKinsey and Company, EU member states will need to invest approximately USD 1.5 trillion (EUR 1.1 trillion) in new technologies over the next fourteen years in order to achieve their targets. In preparation for the new push toward alternative and renewable energy sources, the European Investment Bank has announced plans to earmark slightly over USD 1 billion (EUR 800 million) for loans for renewable energy projects from 2007 to $2010 .^{22}$ In addition, the Commission envisions a 50 percent increase in EU spending on carbon technology over the next seven years. Although the EU approach appears to be focused largely on developing new and alternative technologies, the McKinsey study suggests it may be more cost efficient for the EU to focus more of its efforts on reducing energy use than on developing and promoting alternative and renewable energy sources.

The Russia-Ukraine and Russia-Belarus oil and gas crises have also ignited calls from the European Commission and several EU member states to increase foreign policy coordination to secure and diversify Europe's energy supply. To this end, EU member states have agreed to cooperate to create an external policy centered on expanding political partnerships with, and increasing pipeline and energy infrastructure investment in, producer and transit countries. European states have specifically singled out Central Asia and the Caspian and Black Sea areas as focal points for such activities. In addition, the EU has called for the formation of a European energy dialogue with African countries of strategic importance. With regard to Russia, member states are seeking to institutionalize a common commitment to market principles as outlined in the Energy Charter Treaty in a new EURussia Partnership and Cooperation Agreement. However, bilateral energy agreements between some member states, notably Germany and Russia, illuminate continued dis-

21 The United Nations Kyoto Protocol, to which the United States is not a party, is set to expire in 2012. European leaders reportedly see 2009 as the deadline for international agreement on a post-Kyoto treaty.

22 "EU's 2020 Energy Goals to Cost over 1 Trillion," EU Observer (28 March 2007). 
agreement within the EU on how best to deal with Russia. In the face of such discord, the EU is seeking to strengthen multilateral mechanisms, including the Energy Charter, to better coordinate global energy policy among consumer, transit, and producer nations.

Many observers consider the European Commission's call to increase competition within and among traditionally protected European energy markets to be its most controversial proposed step. The Commission has advanced proposals to reduce the power of state-owned energy companies by forcing them to split up ownership of generation and distribution businesses. In the face of opposition from countries such as Germany, France, and Spain, the Commission is reportedly seeking backing for a compromise proposal that would allow national energy industries to continue to operate both generation and distribution facilities, but would subject them to oversight from an independent European regulatory body. The Commission is expected to present a formal proposal in the fall of 2007.

Although European leaders increasingly pay lip service to the need for enhanced energy cooperation, the success of an EU energy strategy will likely depend on the ability of member states to frame common objectives in addressing three fundamental challenges. First, how to develop strong partnerships with energy producing and transit regions; second, how to use and further develop indigenous and alternative energy sources while seeking to curb overall consumption; and third, how to establish an internal system to provide dependable and secure energy supplies to all of Europe.

\section{Challenge 1: An External Policy for Energy Security}

Growing energy demand within the EU's twenty-seven member states is mirrored in regions throughout the world. ${ }^{23}$ Economic expansion in China and India has added considerably to global demand, as has rising population growth and economic modernization in Latin America, Africa, and even the energy-rich Middle East. In the face of this strain on limited supplies, Europeans must compete for existing and new energy sources. Projections for European energy consumption indicate that one of the most important energy security challenges facing the EU over the next twenty years will be Europe's ability to diversify the sources and modes of transit of its energy imports.

The bulk of the world's energy resources-located in Russia, the Caspian Sea region, the Middle East, and North Africa - are all well within the economic reach of the European Union. In fact, Europe already receives energy supplies from each of these regions. However, Europe's growing dependence on Russia and Russia's apparent willingness to use its energy resources for political purposes have spurred calls from some member states and the United States for a more cohesive EU-wide strategy to further diversify supply. The key for Europe may be to determine the equilibrium point for supply from each geographic region and how to best manage relations with the governments in those regions. By strengthening political relations with these governments, the EU opens additional options for its external energy strategy. According to some, the EU strategy in this regard differs from the stated aim of many U.S. politicians and Bush Administration officials in that Europeans acknowledge they can never gain complete energy independence and therefore

23 The European Commission estimates that European electricity demand alone is growing by 1.5 percent annually. See "An Energy Policy for Europe," op. cit. 
seek to better manage their energy dependence rather than achieve outright energy independence. $^{24}$

EU member states have endorsed the Commission's calls to develop a collective international energy policy. Nonetheless, while acknowledging that the EU may at times be in a better position to determine what leverage could be used to advance the collective interests of the Union as a whole, member states have been careful not to sacrifice their individual rights to independently pursue foreign policies dedicated to securing energy supplies. Europe's energy relations with Russia best exemplify the tension between calls for a collective external energy policy and support for individual member state policies. Many of the EU's newer member states in Central and Eastern Europe appear skeptical of Russia's reliability as an energy partner, and therefore call on EU member states to work collectively to prevent Russia from exploiting long-term energy dependencies for political purposes. At the same time, other member states continue to pursue long-term bilateral supply contracts with Russia's state-run energy companies, increasing both their energy and, according to some, their political dependence on Russia.

Russia. ${ }^{25}$ Russia is a major player in world energy markets. In 2004, its 1700 trillion cubic feet (tcf) of natural gas reserves were the largest of any country, making it both the world's largest gas producer and exporter. Russia is also the world's second-largest oil exporter. According to the European Commission, EU member states imported 29 percent of their natural gas and 26 percent of their oil from Russia in $2004 .{ }^{26}$ With gas consumption expected to rise more dramatically than oil consumption in the future, some experts predict that Europe could rely on Russia for more than 40 percent of its natural gas by $2020 .^{27}$ While Russia's resources and proximity to Europe make Euro-Russian collaboration a necessity, Russia's apparent willingness to use its energy wealth to achieve controversial foreign policy objectives has fueled debate within Europe on how best to manage energy relations with Russia.

Most observers contend that Russian president Vladimir Putin views his country's vast energy resources as a tool to regain Russia's stature as a major force in global affairs. ${ }^{28}$ Thus, Putin sees energy as an important political force, just as it is the dominant force driving Russia's economic development. Some experts believe that Russia seeks to control as much of Europe's energy infrastructure as possible in return for its delivery of reliable energy supplies. For these experts, Moscow knows that if the EU is successful in creating a Europe-wide single market for electricity and gas, which is discussed later in this article, "it will be presented with opportunities to become part of the world's largest and most in-

24 Interviews with German and EU officials, January-March 2007.

25 For additional information on Russia's energy situation see Pirog and Gelb, Russian Oil and Gas Challenges.

26 "EU Energy Policy Data," European Commission Document SEC(2007)12.

27 Keith Smith, "Russian Energy Pressure Fails to Unite Europe," Eurofocus 13:1 (Washington, D.C.: Center for Strategic and International Studies (CSIS), 24 January 2007); available at www.csis.org/index.php?option=com_csis_pubs\&task=view\&id=3704.

28 Keith Smith, CSIS, "Russian Energy Policy and Its Challenges to Western Policy Affairs," testimony before the U.S. Congress, 16 May 2006. 
tegrated energy market right on its border." 29 According to analyst Daniel Yergin, "Putin believes that energy security is about [Russia's] retaking control of the 'commanding heights' of the energy industry and extending that control downstream....", “c

Energy's political importance is evident in the fact that the two major Russian energy giants, Gazprom and Rosneft, both have close ties to the Kremlin and, in particular, to President Putin himself. Rosneft is led by a close associate and former KGB colleague of Putin. Gazprom is run by Alexy Miller, a close Putin ally, and Dimitry Medvedev, Russia's First Deputy Prime Minister, who is presently poised to take over as president when Putin steps down from power in early 2008. Gazprom dominates the Russian gas sector, and controls 100 percent of Russian gas flowing to the EU.

On the investment side, analysts also see Russia playing the political card. The International Energy Agency estimates that the Russian gas sector will require upwards of USD 10 billion in annual investment to meet future global demands. The EU has urged Russia to provide European energy companies the opportunity to invest in the total range of the energy sector, from oil and gas fields to the pipeline system. Thus far, Russia has refused to meet EU demands, and in turn has warned the EU not to attempt to block Gazprom's plans to buy or invest in firms in Europe's energy sector. Brushing aside the EU's policies regarding competition and monopoly practices, as well as the Energy Charter, Gazprom CEO Miller told EU ambassadors in a not so veiled attempt to exert Russia's energydriven influence that "attempts to limit Gazprom's activities in the European market ... will not produce good results.... It is no coincidence that competition for energy resources is growing ... and it should not be forgotten that we [Gazprom] are actively seeking new markets such as China...."

Rather than rely on significant outside investment in its energy infrastructure, observers believe Russia intends to satisfy its long-term gas contracts with European nations through its near monopoly on gas from Central Asia (Kazakhstan, Turkmenistan, and Uzbekistan). Russia currently controls the overwhelming majority of oil and gas transportation routes from Central Asia and, according to analysts, intends to exploit this control and its political leverage over Central Asian governments and European countries to impede European and U.S. efforts to develop alternative pipelines that bypass Russia. For example, critics of Gazprom activities, such as analyst Vladimir Socor, believe that Gazprom's strategy is to "establish permanent control of the [Hungary/Balkans] markets before Caspian gas can reach them through the proposed Nabucco pipeline.....32 In moving ahead with this deal, critics believe Gazprom will try to convince other nations that agreed to fund the Nabucco pipeline to withdraw their commitments and rely on the Russia-Hungary pipeline instead. These critics also warn that Russia's state-owned energy companies aim to increase their

29 Andrew Monaghan, "Russia-EU Relations: An Emerging Energy Security Dilemma," Pro et Contra 10:2-3 (Summer 2006); available at http://www.carnegieendowment.org/publications/ index.cfm? fa $=$ view\&id=18494\&prog=zru.

30 Daniel Yergin, “What Does Energy Security Really Mean?," Wall Street Journal (11 July 2006).

31 Gazprom CEO Miller in a speech to EU ambassadors in Brussels, as reported by BBC News, 4 April 2006.

32 Vladimir Socor, "Gazprom Broadens, Deepens Inroads Into European Union's Internal Markets, Transport Systems," Eurasia Daily Monitor (21 March 2006). 
influence in the face of further European diversification by seeking to acquire controlling stakes in natural gas concerns in North Africa. ${ }^{33}$

The European Response. EU member states have established two primary institutional mechanisms with which to collectively address energy relations with Russia: the Energy Charter Treaty and the EU-Russia Energy Dialogue. As outlined above, the Energy Charter Treaty, which Russia has signed but not ratified, would oblige Russia to adopt a legal framework governing investment, transit, and trade in energy resources. Some analysts contend that European leaders should make Russian implementation of the Treaty a requirement of any future EU-Russia Partnership and Cooperation Agreement. Such calls have contributed to delays in current negotiations of such an agreement and have hindered progress on the EU-Russia Energy Dialogue.

Even as the EU leadership in Brussels moves forward with its ideas on a common external energy strategy, many question how far individual member states will agree to push Russia (and Gazprom) to adopt the EU's principles of competition, open its energy sector to outside investment, and ratify the Energy Charter. Some believe that without such Russian concessions, Europe will ultimately find its energy security largely under Russian control. Indeed, several member states have pursued bilateral energy deals with Russia that will increase their dependence on Russia for years to come. Both Germany and Italy, the largest importers of Russian gas, have negotiated long-term deals with Russia to lock in future gas supplies. For Germany and a few others, "Russia's role as a key supplier of oil and gas makes Putin a vital strategic partner who cannot be ignored or antagonized." 34 Such deals are not limited to the major energy consumers. Slovenia and Belgium have entered into negotiations with Gazprom to build a pipeline across the former and to enter the gas distribution market in the latter. Hungary's oil and gas company, Mol, has joined with Gazprom to extend Gazprom's Blue Stream pipeline across the Black Sea through the Balkans into Hungary.

These examples of individual member states dealing with Russia bilaterally have drawn harsh criticism from other member states, such as Poland and the Baltic states. They have warned their European colleagues not to make energy deals that will give Russia an undue and possibly dangerous amount of political influence over European decision-making. Many of these nations understand that Europe's dependence on Russian energy is likely to last no matter what alternatives are included in an EU energy policy. But they also feel Europe does not gain real security by becoming more dependent on Russia. In fact, the growing presence of Gazprom throughout the European energy market has led many to worry about the EU's ability to develop an energy policy insulated from Gazprom's influence. ${ }^{35}$ In a July 2006 speech, Romania's President Basescu went so far as to

33 Keith Smith, "Russian Energy Pressure Fails to Unite Europe."

34 William Drozdiak, "Russia: More Awkward, But Still Indispensable," European Affairs 7:1-2 (Spring/Summer 2006); available at http://europeanaffairs.org/current_issue/2006_spring_summer/ 2006_spring_summer_13.php4.

35 Comments provided through discussions with representatives of several European member states. 
warn that "Europe's dependence on Russian gas monopoly Gazprom ... could be the biggest threat to the region since the former Soviet Union's army." 36

Initial efforts to institutionalize interaction between the EU and Russia on energy issues came to fruition in 2000 with the creation of the EU-Russia Energy Dialogue. However, results of the Dialogue have reportedly been mixed at best. Despite continued Russian reluctance to allow European investment in its energy sector and to adopt the energy market and transportation principles laid out in the Energy Charter, several European nations continue to pursue policies that result in increased Russian influence in their energy sectors. On the other hand, 2006 negotiations on a renewed Russia-EU partnership agreement were derailed due to Polish and other member state concerns regarding Russian intransigence in several areas, including energy cooperation. Putin and EU leaders have announced their intention to negotiate a renewed agreement with a significant energy component in the first half of 2007; however, neither side has demonstrated a willingness to make significant changes in their approach to the issue. ${ }^{37}$ In the face of internal discord, the EU appears to have agreed to focus on achieving its energy goals with regard to enhancing sustainability, while Russia has shown few signs of deviating from its recent policies.

The energy situation with Russia is not yet dire. Russia will continue to be Europe's primary energy supplier for the long term, and healthy Russian-European relations remain a priority on both sides. If a common external EU energy security policy is to emerge, two options may be considered. First, Europe may move to curb its dependence on Russian energy by diversifying its supply from other regions without threatening Russia's own market security in Europe. In doing so, Europe might ask if there is a point at which Russia could decide that the EU's commitment to diversification no longer makes it financially attractive for Russia to continue to invest in new supplies destined for the European market. Second, the EU may attempt to regulate the behavior and practices of Gazprom as it becomes a more dominant energy player in Europe. Thus far, few European countries have demonstrated restraint in seeking bilateral deals with the Russian monopoly that would do just that. If this continues, Europe could risk having Gazprom interfere more and more in its internal political decision-making. To avoid this, the European Union will likely continue to apply pressure on Gazprom to play by Europe's rules on competition and work to change Gazprom's corporate mentality by allowing European firms to invest in Russia's gas industry.

According to some analysts, however, internal discord on how to approach Russia is preventing the EU from applying this kind of pressure. These critics argue that the EU could collectively pressure Russia by enforcing existing EU competition laws and even using Russia's prospective World Trade Organization (WTO) membership as leverage to open Russia's domestic energy sector to outside investment. ${ }^{38}$ On the other hand, countries such as Germany appear reluctant to take any concerted action that may antagonize Russia,

${ }^{36}$ President of Romania Traian Basescu, in a speech to the Jamestown Foundation in Washington, D.C., July 2006.

37 “Merkel Calls for Improved EU-Russia Energy Ties," Deutsche Welle (21 January 2007); available at www.dw-world.de/dw/article/0,2144,2320330,00.html.

38 Keith Smith, "Russian Energy Pressure Fails to Unite Europe." 
citing the need for a healthy strategic partnership, given Euro-Russian mutual dependencies and the importance of Russian cooperation in addressing other issues of global concern, such as the Iranian nuclear program and the future status of Kosovo. ${ }^{39}$

Central Asia and the Caspian / Black Sea Regions. ${ }^{40}$ One of the focal points of European energy diversification strategies is Central Asia and the Caspian and Black Sea regions. Indeed, the EU's January 2007 energy policy paper recommends strengthening the EU's so-called Neighborhood Policy with these areas, and European leaders have sought to bolster ties with countries in these regions.

The Caspian Sea in Central Asia is bordered by Azerbaijan, Iran, Kazakhstan, Russia, and Turkmenistan. After the collapse of the Soviet Union, the international community took an active interest in the region because of the potential oil and gas reserves thought to be located in at least six identified hydrocarbon fields beneath the Caspian Sea.

Presently, the Caspian Sea region is a significant, but not major, supplier of crude oil to world markets. The untapped reserves held by four of these nations might offer Europe an opportunity to gradually pull back from increased dependence on Russian energy. Estimates of the Caspian Sea region's proven oil reserves range between 40 and 50 billion barrels. Production levels in 2005 were estimated to be around 2 million barrels per day. The Caspian Sea region's natural gas reserves are estimated at 232 trillion cubic feet (tcf). Natural gas production in 2004 was approximately 5 tcf.

Europe's formal interest in the energy resources of the region dates back to 1995 with the creation of the Interstate Oil and Gas Transport to Europe program (Inogate). This EU initiative (currently with twenty-one member countries) was designed to promote the construction of regional pipeline systems in order to facilitate the transport of oil and gas to Europe. ${ }^{41}$ This was followed by another EU proposal, the "Baku Initiative," which was launched in November 2004 with the participation of the European Commission and the Black and Caspian Sea littoral states. The Baku Initiative was designed to facilitate the progressive integration of the energy markets of the region into the EU market as well as the transportation of the extensive Caspian oil and gas resources to Europe.

At the time Inogate was formed, Russia dominated both oil and gas production and distribution in the region. Since most of the countries involved are landlocked, their oil and gas had to be transported via pipelines. Reflecting Soviet-era dictates and infrastructure, nearly all Caspian crude oil traveled north or west via pipeline to or through Russia to European markets. Some oil also went by tanker through the Bosporus Straits to Western European markets via the Mediterranean. Natural gas transportation was tied to pipelines traveling mainly north or west through Russia and its monopoly pipeline system, controlled by Gazprom. This has provided Russia with the market power to dictate, in part,

39 Interviews with German officials, January-March 2007.

40 For more information, see Bernard Gelb, Caspian Oil and Gas: Production and Prospects, CRS Report RS21190 (Washington, D.C.: Congressional Research Service, updated September 2006); available at http://italy.usembassy.gov/pdf/other/RS21190.pdf. See also Jim Nichol, Central Asia: Regional Developments and Implications for U.S. Interests, CRS Report RL30294 (Washington, D.C.: Congressional Research Service, updated April 2007); available at http://fpc.state.gov/documents/organization/86258.pdf.

41 A more detailed account of the activities of Inogate is available on its website at www.inogate.org. 
the price it is willing to pay for the oil or gas; to set transit fees on Caspian energy shipped through its transportation network; and to determine in some cases how much, if any, it is willing to transport. This latter point was made evident in 2005 when Russia's oil pipeline company, Transneft, refused to allow oil from Kazakhstan to be shipped through its pipeline system to Lithuania for refining. The Caspian region nations thus have incentives to develop alternatives to routes through Russia to reach European and other markets and to seek leverage in negotiating transit fees on shipments that do go through the Russian pipeline system.

Changing Central Asia's energy flow from the existing North-South axis to an EastWest axis toward Europe could be integral to Europe's energy strategy. Currently, the region relies on three big pipeline projects that will reduce the region's dependence on Russia. The Caspian Pipeline Consortium (CPC) project connects Kazakhstan's Caspian Seaarea oil deposits with Russia's Black Sea port of Novorossiysk. Oil loaded at Novorossiysk is then taken by tanker to world markets via the congested Bosporus Straits. ${ }^{42}$

The Baku-Tbilisi-Ceyhan oil pipeline (BTC), which opened in July 2006, exports oil from Azerbaijan and up to $600,000 \mathrm{bl} / \mathrm{d}$ from Kazakhstan along a 1040-mile route from Baku, Azerbaijan via Georgia to the Turkish Mediterranean port of Ceyhan. This will allow oil to bypass the Bosporus Straits.

The South Caucasus Pipeline (SCP), a new gas pipeline venture completed in December 2006, runs parallel to the BTC oil pipeline for most of its route before connecting to the Turkish energy infrastructure and on to Europe via a transit pipeline through Greece.

In addition to these pipelines already in service, several additional projects in Europe could be involved. One option for additional oil transport would be to upgrade the existing oil pipeline that runs from Baku in Azerbaijan to Supsa in Georgia. That line could be extended under the Black Sea, or the oil could be loaded onto tankers and shipped to Odessa, Ukraine. The oil could then be pumped through the Odessa-Brody pipeline into Poland. Some, including the Poles, have suggested that the Brody line be extended to northern Poland and possibly into the Baltic states for use at the Mazeikai refinery in Lithuania.

On the gas front, two additional projects offer important options for Europe. One, the Trans-Caspian pipeline, is intended to bring additional gas from the Caspian to Georgia and across the Black Sea to Romania and the Balkans. The other pipeline, Nabucco, is scheduled to be built in 2008 and would carry gas through Turkey into Bulgaria and on to Austria. This project has the financial backing of several European nations and the endorsement of the EU. Both pipelines have been opposed by Russia, and Gazprom is trying to peel off the support of at least Hungary by offering an alternative service.

There can be no doubt that the energy resources of the Caspian Sea region can offer Europe a viable alternative source of energy supply. However, the full realization of the energy potential of the region could be impeded by several factors.

One issue that continues to raise questions regarding regional stability is the unresolved legal status of the Caspian Sea. Despite a number of efforts, so far only Azerbaijan,

42 Additional analysis of the Caspian region can be found in Energy Information Administration, "Country Analysis Brief: Caspian Sea," U.S. Department of Energy (January 2007); available at www.eia.doe.gov/cabs/Caspian/Background.html. 
Kazakhstan, and Russia among the littoral states have reached agreement on delineating ownership of the Sea's resources or their rights of development. The EU could offer its legal assistance to help resolve outstanding issues.

A second issue is the ability of the EU to work to ensure the long-term political stability of the region. The conflict between Azerbaijan and Armenia over Nagorno-Karabakh leaves the BTC and the future SCP pipelines vulnerable to sabotage. Internal political strife between Georgia and its two breakaway regions (Abkhazia and South Ossetia) also threatens future pipelines through that country. Continued political uncertainty in Ukraine and growing Iranian influence in the southern Caucasus could deter future long-term investment by the private sector. However, the January 2007 entry of Romania and Bulgaria into the European Union and the EU's special relationship with Turkey should help keep the Black Sea region settled.

A third issue involves the willingness of the EU to compete with Russia for political and economic influence in the region and to prevent Gazprom from closing off the Caspian market (or at least the Central Asian part of the region) to Europe and its private sector. Russia's higher priced gas exports to Europe depend on Gazprom's ability to control the flow of gas from Kazakhstan and Turkmenistan. This dependency is expected to increase over the next seven to ten years until Russia's huge gas fields in the Barents Sea come on line. ${ }^{43}$ According to some, although Gazprom was unable to prevent the BTC pipeline from being completed, Gazprom intends to continue to press the countries around the Black and Caspian Sea regions to agree to gas supply and transit arrangements that satisfy the company's goals of channeling lower-cost Central Asian gas to Russian customers and protecting its lucrative European market. ${ }^{44}$ Gazprom has already locked up much of Turkmenistan's gas in a twenty-five-year contract, and is pursuing a similar strategy toward Kazakhstan.

The final issue revolves around whether Europe is the optimal market for Caspian oil and natural gas. Oil demand over the next ten to fifteen years in Europe is expected to grow by little more than 1 million bl/d. Oil exports eastward, on the other hand, could serve Asian markets, where demand for oil is expected to grow by roughly 10 million bl/d over the next fifteen years. ${ }^{45}$ In fact, China, which opened an oil pipeline to Kazakhstan in 2005, sees Kazakhstan as a major source of oil for the long term.

The Caspian region will continue to be an important source of energy production for the foreseeable future, especially if the estimates of its reserves (particularly its gas reserves) are accurate. Thus, the region can contribute to the diversification of oil and gas supplies to Europe, which will add to Europe's energy security. Taking full advantage of this potential will require a strong commitment on the part of the EU to encourage the private sector to take the financial risks associated with securing a share of the Caspian energy market for Europe, and to set forth an external strategy that is fully prepared to address the dynamics of the entire region. For some, "a credible energy [strategy] needs to

43 Keith Smith, "Russian Energy Policy and Its Challenges to Western Policy Affairs."

44 Zeyno Baran, "Energy Supplies to Eurasia and Implications for U.S. Energy Security," testimony before the U.S. Senate Foreign Relations Committee, September 2005.

45 Gelb, Caspian Oil and Gas: Production and Prospects. 
demonstrate that the EU means business in the Caspian/Black Sea regions. Brussels must include energy supply and transit as high priorities ... for the region."

Middle East/North Africa. EU efforts to diversify European energy supplies and decrease dependence on Russia have heightened calls within Europe for stronger political and economic engagement in the Middle East and North Africa. However, political instability in the region and strong competition for its energy resources from countries in Asia and North America present challenges to European efforts.

The Persian Gulf countries (Bahrain, Iran, Iraq, Kuwait, Qatar, Saudi Arabia, and the United Arab Emirates) alone hold over half (57 percent) of the world's proven oil reserves, and the Middle East region produces about 31 percent of the world's oil. ${ }^{47}$ In addition, Libya is estimated to hold 40 billion barrels (bb), and Algeria 12 billion barrels. The Persian Gulf region also holds an estimated 2400 trillion cubic feet (tcf) of natural gas reserves, representing 45 percent of the world's total gas. Algeria is estimated to hold 161 tcf, and Libya 52 tcf. $^{48}$

Europe already depends on the Middle East/North Africa region for close to 30 percent of its oil imports and approximately 15 percent of its piped gas. In 2005, Europe imported approximately 3.1 million barrels a day of oil from the region. The largest portion of that oil comes from Saudi Arabia, followed by Libya and Iran. ${ }^{49}$ Europe's primary supplier of natural gas has been Algeria, via two pipelines that enter Europe through Italy and Spain. A smaller amount comes from Libya via pipelines to Italy. Two additional gas pipelines from Algeria to Spain and Italy are under construction.

Perhaps the most important development for Europe in this region has been the growing availability of liquefied natural gas (LNG). Today, Europe accounts for approximately 8 percent of the world's total consumption of LNG, and in 2005, LNG represented 15 percent of European gas imports - a 21 percent increase from 2004. ${ }^{50}$ Spain, where 65 percent of gas imports are LNG, leads Europe in LNG imports, followed by Portugal (39 percent) and France (27 percent). The principal suppliers of LNG to Europe include Algeria, Egypt, Oman, and Qatar. Algeria is the world's third-largest exporter of LNG, with almost all of its gas ( 25 billion cubic meters) going to Europe. Recently, the Algerian national oil company, Sonatrach, signed a twenty-year LNG supply contract with the Spanish power company Endessa. ${ }^{51}$

LNG has also become a major factor in the development of gas exports from the Persian Gulf. Although nations such as Qatar, Oman, and the United Arab Emirates have produced LNG for the Asian market, European energy companies have begun to express more

46 Vladimir Socor, "What Role for the Black Sea Region in the European Union's Energy Strategy," Eurasia Daily Monitor (3 March 2006).

47 For additional information see Energy Information Administration, "Persian Gulf Oil and Gas Exports Fact Sheet," U.S. Department of Energy (April 2003); available at www.parstimes.com/ library/persian_gulf_doe_2003.pdf.

48 See British Petroleum (BP), Statistical Review of World Energy, June 2006.

49 "EU Energy Policy Data."

50 Statistics from Eurogas, at www.eurogas.org.

51 As reported by Lloyd's List, 25 May 2006. 
of an interest in purchasing LNG from the Gulf as well. With vast amounts of gas reserves, the Gulf states are positioned to meet a portion of Europe's future demand.

European relations with the states of the Persian Gulf and North Africa have steadily improved over the years. EU relations with North Africa were formalized in 1995 with the creation of the Euro-Mediterranean Energy Partnership. The EU has also created the EUGulf Cooperation Council (GCC) Dialogue with the states of the Persian Gulf, and has initiated a formal dialogue with the nations of OPEC. European energy companies have also become more involved in the Middle East.

The potential for growth in Europe's energy diversification strategy with respect to the Middle East and North Africa is significant. However, European competition with Asia and North America and long-term political instability throughout the region will likely temper the degree to which Europe seeks to increase its reliance on the region. Nevertheless, as with the Caspian region, if the EU is serious about lowering its dependency on any one source, it must turn more and more to the Middle East and North Africa. Parenthetically, Europe's growing interest in energy resources in North Africa has not gone unnoticed by Russia and Gazprom. Just as in the Caspian region, Russia appears to be bolstering its efforts to influence Europe's energy plans. In March 2006, President Putin, along with Gazprom officials, traveled to Algeria to discuss Russian participation in Algeria's future oil and gas projects, including its LNG export markets. Some contend that because Russia intends to make Europe a major market for LNG produced from its Shtockman gas field in the Barents Sea, Russia is seeking to position itself to influence Algeria's future role as a major supplier of energy to Europe.

Norway. Norway, which is not a member of the EU, is the second-largest exporter of natural gas to the EU, behind Russia. Norwegian exports represented 17 percent of European gas consumption in 2004. Germany (which imports 25 percent of it natural gas from Norway), France (30 percent), and the United Kingdom (30 percent) are the largest consumers of Norwegian gas exports. ${ }^{52}$ As of January 2005, Norway had 73.6 trillion cubic feet (tcf) of proven natural gas reserves. The North Sea holds the majority of these reserves, but there are also significant quantities in the Norwegian and Barents Seas. Norway is the eighth-largest natural gas producer in the world, producing $2.59 \mathrm{tcf}$ in $2003 .{ }^{53}$ The United States Geological Survey has estimated that almost 25 percent of the globe's yet to be discovered resources are located in the Arctic region. Norway's recently opened Snohvit gas field, along with Russia's field at Shtockman, will make the Barents Sea a new European energy region.

According to industry estimates, Norway had 8.5 billion barrels of proven oil reserves as of January 2005, the largest in Western Europe. The bulk of Norway's oil production occurs in the North Sea, with smaller amounts in the Norwegian Sea. In 2005, Norway's oil production averaged 2.95 million bl/d. As North Sea fields continue to mature, Norwegian oil production will likely remain steady for several more years and then begin to decline. There is some hope that new developments in the Barents Sea will offset some of

52 Jonas Store, Minister of Foreign Affairs, Norway, "The High North-Top of the Agenda," Speech at CSIS, Washington, D.C., June 2006; "EU Energy Policy Data."

53 Energy Information Administration. 
this decline. The largest single recipient of Norway's oil exports is the United Kingdom, which imports around 814,000 bl/d from Norway, or 34 percent of Norway's total exports. Other significant destinations include the Netherlands and Germany.

Norway's entry into the LNG export market opens a new opportunity for the EU to work with its northern neighbor on energy security issues. Norway's energy giant, Statoil, plans to construct the first large-scale LNG export terminal in Europe, with connections to the Snohvit project. Although the initial LNG production from the Snohvit project has been committed to the United States, follow-on production and gas from future fields in the Barents Sea could be shipped to facilities in Europe. The EU has recognized the growing importance of Norway in Europe's energy security debate, and has expressed interest in "facilitating Norway's efforts to develop resources in the high north of Europe." Individual European nations have also recognized Norway's potential future role in providing secure energy. Poland, along with the Baltic states, has already begun discussing with industry the construction of an LNG terminal along the Polish coast to receive LNG from Norway for transport to other parts of Europe.

Conclusion. Establishing a diversified network of secure energy suppliers has become one of the foremost challenges facing the nations of Europe. In one sense, Europe is fortunate to have such large sources of available energy within a relatively small geographical space. However, like other countries, Europe faces the fact that, for the foreseeable future, those energy producing nations pose different levels of risk, ranging from outright political instability to more subtle questions of political reliability and long-term intentions.

The EU can continue to use its Common Foreign and Security Policy (CFSP) and collective trade policy to promote political stability and security in countries providing the bulk of Europe's energy supply. However, perspectives on energy security policy differ among the twenty-seven member states themselves, and between the states and the European Commission. Long-term bilateral energy agreements such as the Baltic pipeline agreement between Russia and Germany, and LNG contracts signed between Spain and France and Algeria demonstrate that member states continue to view energy security primarily as a national policy issue. Such bilateral agreements may or may not take broader Union security into account. However, they could become more commonplace unless member states agree that a continued reluctance to coordinate may threaten the long-term energy security of the Union, especially if the states gravitate to single energy suppliers. For many, the European Commission's proposals that serious consideration be given to a common European energy policy make sense. Nonetheless, progress toward a common external energy security strategy tied to the EU's CFSP appears to require greater coordination than has been demonstrated heretofore.

\section{Challenge 2: Promoting Indigenous Energy Supply}

While efforts to develop a coherent external energy policy remain a top priority for the European Commission and some member states, there is broad European agreement that the EU should also look inward to determine how its dependence can be mitigated by making better use of indigenous energy supplies. Specifically, the EU has taken steps to

54 European Commission Green Paper, op. cit. 
increase Europe-wide production and use of alternative and renewable energy sources and to invest in "clean coal" technology. These efforts are aimed both at increasing European energy independence and addressing growing public and political concern with the effects of energy consumption on global climate change. Accordingly, current initiatives are focused on the two sectors that together account for a significant majority of the EU's total carbon-dioxide emissions: power and heat generation (39 percent of total carbon emissions) and transport (26 percent). ${ }^{55}$ Energy consumption in the transport sector is overwhelmingly fueled by imported oil. About a third of Europe's power generation comes from coal burning plants, and another third from nuclear plants. The following chart illustrates the breakdown of power generation by fuel.

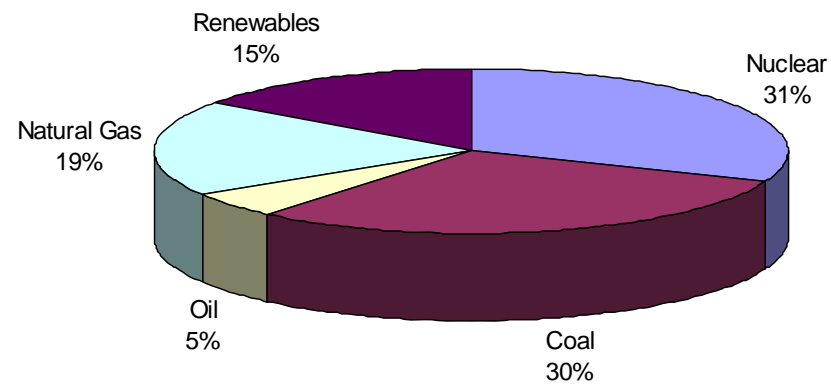

Figure 2: EU Electricity Generation by source, $2005^{56}$

The mix of energy supply in EU member states continues to be determined largely by national governments or energy companies. As a result, energy mix varies widely across the EU, influenced by a number of factors ranging from resource cost and availability to political factors, such as legislation curbing nuclear energy production. In France, for instance, nuclear power accounts for over 70 percent of all electrical generation, while Germany and Spain have enacted laws to phase out the use of nuclear power; in Poland and the Czech Republic, on the other hand, coal is the dominant fuel.

Nonetheless, decisions regarding national energy mix are increasingly influenced by EU and international agreements to reduce greenhouse gas and carbon emissions. Under the 1997 Kyoto Protocol, the EU is obligated to reduce its carbon emissions by 8 percent of 1990 levels by 2012. In order to achieve this collective target, member states have agreed to individual National Action Plans, with heavily coal-reliant and less economically developed member states such as Poland committed to less stringent targets than countries with more developed renewable energy portfolios. Member states will take the same approach to realizing the EU's most recent goals of reducing emissions by 20 percent of 1990 levels by 2020. National targets are expected to be agreed upon by the end of 2007 .

55 In 2004, Europe's power and heat generation and transport sectors accounted for a combined total of 2,433 million tons of the EU's carbon-dioxide emissions, out of a total of 3,863 tons. Directorate-General of Energy and Transport, Statistical Pocket Book 2006.

Source: IEA. 
The EU's ability to reduce its import dependence while mitigating negative environmental effects will depend largely on individual member state decisions regarding energy mix. European efforts are expected to focus on promoting renewable energy and cleaner burning fuels, developing "clean coal" technology, and increasing energy efficiency and reducing overall consumption. Because nuclear power generation does not directly produce carbon emissions, some experts and government officials advocate an increase in nuclear power generation. Others, on the other hand, cite safety and proliferation concerns in opposing a rise in nuclear power generation.

Coal. Just over one-third of all electricity generated in Europe is produced by burning coal. As with other energy sources, coal use and production varies among member states. Coal burning accounts for the bulk of electricity production in member states such as Poland (92 percent), the Czech Republic (65 percent), Greece (62 percent), and Germany (just over 50 percent), but has been almost completely phased out in countries like France, which relies largely on nuclear power. Despite the fact that coal burning accounts for close to 25 percent of the EU's total carbon dioxide emissions, its abundance-Europe has proven reserves of close to 40 billion tons-leads most analysts to believe that coal will continue to play a significant role in Europe's energy consumption patterns. ${ }^{57}$ Given Europe's continued reliance on coal, and acknowledging the "huge possible benefits of a sustainable use of [coal]," the EU has moved to invest in technologies, such as carbon capture and sequestration (CCS), that will enable so-called clean coal burning. Current technology is thought to enable efficiencies of well above 60 percent, but the majority of Europe's older and even most recently built plants have efficiencies ranging only from 30 to 43 percent. $^{58}$

EU member states have endorsed Commission efforts to foster technological advances in the area of clean coal burning and to bring twelve sustainable fossil-fuel power plants on line by 2015 . Nonetheless, in the long term, the ability of member states to meet their commitments to lowering carbon emissions, the potential for using renewable energy, the price of natural gas, and the cost of installing clean coal burning technologies will likely dictate whether coal can remain a viable alternative energy source for Europe.

Nuclear. Although nuclear power accounts for roughly one-third of Europe's overall electrical generation, pronounced differences in national nuclear energy policies have prevented the EU from developing a common nuclear energy policy. There are approximately 175 nuclear reactors in operation in Europe today. However, while nations such as France, Finland, Sweden, and the United Kingdom rely heavily on nuclear power, others oppose it on the grounds that it is dangerous and creates difficult waste disposal problems. Germany and Spain, for instance, have committed to phasing out all of their nuclear reactors over the next several years and replacing those with gas powered facilities. Political pressure to

${ }^{57}$ European Commission, Sustainable Power Generation from Fossil Fuels: Aiming for Near-Zero Emissions from Coal after 2020, COM(2206)843 Final; available at http://eur-lex.europa.eu/ LexUriServ/LexUriServ.do?uri=com:2006:0843:FIN:EN:HTML. European Commission, "Coal Market Outlook," 2005; Coal: a Clean Source for the Future? Euractiv.com (June 2006; updated June 2007); available at www.euractiv.com/en/energy/coal-clean-energy-source-future/ article-156397. 
rethink these decisions - or at least extend timetables for the phase out - is reportedly growing in both countries, and the United Kingdom, Finland, and Lithuania have all decided to add new reactors. Nonetheless, given the substantial costs of putting a nuclear reactor on line and the controversial nature of nuclear waste, it appears unlikely that Europe will see a resurgence of new nuclear reactors in nations where nuclear power does not already play a role. At best, those nations that already utilize nuclear power could be expected to either replace or upgrade existing reactors. On the other hand, advocates of nuclear power generation appear to be gaining favor within Europe, given the fact that nuclear power generation emits virtually no greenhouse gas emissions.

One promising alternative may be found in the International Thermonuclear Experimental Reactor (ITER) program. The EU has joined the United States and several other nations in an effort to produce electrical power from nuclear fusion, which unlike current nuclear power does not generate dangerous waste. The first facility will be constructed in France, but initial results are not expected for at least fifteen to twenty years.

Renewable Energy. Hydro, wind, solar, and bio-mass energy currently account for just under 7 percent of Europe's total energy consumption, and 15 percent of its electricity generation. In March 2007, EU member states agreed to a legally binding target mandating that 20 percent of total European energy consumption be fueled by renewable energy sources by 2020 . Member states are expected to negotiate individual national targets to realize the EU-wide goal by the end of 2007. Countries with advanced renewable energy sectors like Austria, Sweden, and Denmark are expected to set significantly more ambitious targets than newer member states in Central and Eastern Europe. France has reportedly urged special consideration be given to nuclear energy, which is not considered a renewable energy resource by most, but is virtually greenhouse gas emission-free.

Although EU-wide support for renewable energy is strong, individual member states' renewable energy portfolios vary. For instance, Austria and Latvia promote hydropower, while the Czech Republic and Portugal have committed financial support to large solar energy facilities. Germany, Sweden, and the U.K. are home to major wind farms off their coasts. Bio-mass and biofuel programs are becoming more attractive. Given that Europe's oil-dependent transport sector accounts for roughly a quarter of the EU's total carbon emissions, the EU has mandated that biofuels make up a 10 percent share of all European transport fuel by 2020 .

Whether the EU meets its renewable energy targets will likely depend on the cost of production and the extent to which member states are willing to subsidize their development on a large scale. As noted earlier, a March 2007 McKinsey and Company report estimates that EU member states will need to invest approximately USD 1.5 trillion (EUR 1.1 trillion) in new technologies over the next fourteen years in order to achieve their carbon emission and accompanying renewable and energy efficiency targets. It appears that the Commission, the European Investment Bank, and individual member states are poised to substantially increase their investment in these sectors, although specific amounts are difficult to estimate. Some member states have announced programs to subsidize and provide low-interest loans to fund research and development on renewable energies, with 
countries like Germany hoping to create the industrial capacity to supply what German officials believe will become an increasingly lucrative global market for renewable energy. ${ }^{59}$

\section{Challenge 3: Providing Energy Security through An Internal Energy Market}

The European Commission has long argued that member states could substantially increase their energy supply security and network and cost efficiency by integrating national gas and electricity markets into the EU's single European market. ${ }^{60}$ However, despite reforms to liberalize markets in some member states, national energy markets remain largely under state control. As energy security considerations have risen to the forefront of the EU agenda, debate over energy market liberalization has increased. The Commission and some member states contend that market integration and liberalization will increase energy security by forging network connectivity and EU-wide interdependence and diversifying supply sources, while others argue that continued national protection is important to guarantee stable and secure supply and distribution and to protect consumers from fluctuations in an unpredictable free market. ${ }^{61}$ Commission proposals to develop a Europe-wide internal market for gas and electricity transmission and distribution continue to stoke debate, and analysts do not expect member states to take concerted action in this area before 2008 .

The Commission launched its efforts to create a competitive EU-wide gas and electricity market beginning in the mid-to-late 1990s by issuing a series of directives focused on four primary objectives:

- To implement the single market for energy by promoting competition and efficiency in the production and delivery of electricity and gas

- To lower prices and give all EU customers the opportunity to choose their energy supplier by 2007

- To help improve the environment

- To enhance energy security.

However, most member states appear to regard energy policy as too important to their own individual economic development to give up national control over such policy, arguing that in Europe, nationalized industries have, for the most part, provided stability in the energy market. In fact, the dominant position of energy industries in some countries has led some national governments to take measures to protect their industries, even while ostensibly subscribing to the theory of open market competition. ${ }^{62}$

Over the past year, the Commission has increased its efforts to promote EU guidelines to determine ownership and access to electricity grids, pipelines, and emergency energy

59 Interviews with German officials, January-March 2007.

60 The 1986 Single European Act, adopted in 1987, established the so-called single European market, allowing for the free movement of goods, services, people, and capital across the EU.

61 Katinka Barysch, Simon Tilford, and Aurore Wanlin, The Lisbon Scorecard VII - Will Globalization Leave Europe Stranded? (London: Centre for European Reform, 2007); available at www.cer.org.uk/pdf/p714_lisbons_vii_2007.pdf.

62 For additional information see Raymond J. Ahearn, Europe: Rising Economic Nationalism? CRS Report RS22468 (Washington, D.C.: Congressional Research Service, July 2006); available at http://italy.usembassy.gov/pdf/other/RS22468.pdf. 
storage facilities. The Commission's most recent and controversial proposal would reduce the power of state-owned energy companies by obligating them to split up ownership of generation and distribution networks (a process known as unbundling). The Commission contends that dual ownership blocks competition and allows for price manipulation. However, opposition to unbundling from Germany, France, and Spain leads analysts to predict that the Commission will seek to allow national energy industries to continue to operate both generation and distribution facilities, but subject them to oversight from an independent European regulatory body. The Commission is expected to announce its formal proposal in the fall of 2007.

The internal European market for electricity and gas is by no means complete. Despite continued apprehension in some member states and the numerous obstacles yet to be overcome, the Commission contends that by increasing competition, a more open energy market will diversify supply, thereby mitigating the effects of individual dependencies and bolstering EU-wide energy security. Indeed, analysts argue that open markets and competition can guarantee a certain level of security if competitive forces are successful in providing energy from a variety of sources. In a 2004 paper, analyst Giacomo Luciani, referring to the European gas market, suggests that as long as only two sources of energy (Russia and Algeria) continue to dominate gas imports to Europe, it is unlikely that real competition can exist, and that increasing dependence on established suppliers is incompatible with competition. $^{63}$

Network Interconnection. As progress toward a liberalized European energy market continues, discussion on energy security is expected to focus on the internal market's ability to deliver energy supplies through interconnected pipelines and electricity grids and to provide infrastructure security and emergency supply.

The European power transmission grid is divided into seven regional "pools" that, according to the Commission, are only weakly connected. Cross-border energy exchanges have increased recently. For example, in July 2006, the French electricity sector purchased additional power from Germany to offset the demand in France brought on by a heat wave. However, in 2005 , only about 10 percent of the currently installed electrical generation capacity of Europe could be delivered across national borders. Although there are examples of successful cross-border cooperation, especially in regions such as the Nordic pool, many contend that a wave of blackouts in 2005 and 2006 was caused by weak links between Europe's power grids, poor coordination between national and regional power markets, and insufficient generation capacity. As a result, the EU has increased efforts to encourage investment in the construction of cross-border electricity grid connection, as well as to extend this kind of activity to gas, oil, and new LNG distribution systems.

\section{Assessment}

Most EU member states have long held that energy policy should remain the primary responsibility of the states themselves. However, European countries have begun to rethink

63 Giacomo Luciani, "Security of Supply for Natural Gas Markets," INDES Working Paper No. 2, Center for European Policy Studies, March 2004; available at http://ceps01.link.be/files/ No2\%20INDES\%20pdf.pdf.copy. 
energy, not only as an element of individual national security but also as an element of the EU's Common Foreign and Security Policy (CFSP). Furthermore, growing European public and political concern regarding global climate change appears to have spurred European action to mitigate its energy dependence by seeking to increase efficiency and reduce carbon emissions within Europe. Indeed, of the three focal points of current EU energy security policy - external relations, indigenous energy supply, and the internal energy market - efforts to promote a cleaner and more efficient indigenous energy supply have gained the most support from member states.

Some skeptics doubt the ability of EU member states to ultimately come to agreement on a host of energy-related issues, particularly in managing external relations and creating an internal market. There continues to be strong disagreement on how to deal with Russia and on an appropriate diversification strategy, and most decisions regarding foreign supply sources and contract terms will likely remain in the hands of individual member states and their energy sectors. Open and competitive energy markets are desired, but protection of national energy industries still prevails in several key nations, including Germany, France, and Spain. Some countries that have reluctantly agreed to open their energy sectors to more competition appear unenthusiastic about turning regulatory decisions over to European Commission bureaucrats in Brussels.

On the other hand, the EU is increasing its role in coordinating and financing the development of renewable energy and the storage and use of emergency energy supplies. Although member states and their energy industries appear likely to retain absolute authority in determining which energy mix makes the most sense for individual countries, the EU has set binding EU-wide targets in some areas and may continue this trend. The EU also stands to play a larger role in determining power grid interconnection arrangements and energy infrastructure investment levels. With regard to foreign policy, efforts to advance energy dialogues with Russia and other energy producing and transit regions are being pursued in a more open and coordinated manner between the EU's Office of the High Representative for Common Foreign and Security Policy and the individual member states, and the Commission has outlined specific foreign policy goals with regard to multilateral treaties and an expansion of the EU's Neighborhood Policy. Nonetheless, foreign policy continues, first and foremost, to be determined by national governments.

\section{Energy Security in the Transatlantic Context}

Over the past fifty-five years, relations between the United States and the EU have steadily broadened and deepened, so that today they are inextricably linked. Nowhere has transatlantic integration manifested itself more than in the economic relationship between the United States and the European Union. This economic partnership has been described by many as the single most important influence on worldwide economic growth, prosperity, and trade. ${ }^{64}$ Within the deepening transatlantic economic relationship, energy security policy is becoming a higher priority for both the United States and the EU. Together, the

${ }^{64}$ For a more detailed explanation of the economic relationship see Daniel S. Hamilton and Joseph P. Quinlan, Deep Integration: How Transatlantic Markets are Leading Globalization (Brussels: Centre for European Policy Studies, 2005). 
United States and the European Union represent the world's largest energy market. The United States and the EU produce approximately 23 percent of the world's energy, but combine to account for almost 40 percent of global energy consumption. ${ }^{65}$ Combined, the United States and the EU account for almost 40 percent of the world's total carbon emissions. $^{66}$

At the 2006 U.S.-EU Summit, the parties agreed to increase cooperation on energy security, climate change, and sustainable development issues. Three institutional mechanisms to facilitate this cooperation were established: an annual strategic review of U.S.EU energy cooperation; a U.S.-EU High Level Dialogue on Climate Change, Clean Energy, and Sustainable Development; and a U.S.-EU Energy CEO Forum. None of these forums has convened more than once, however, and at the April 2007 U.S.-EU Summit in Washington, D.C., the Bush Administration reportedly rejected European calls for a commitment to pursue binding international global emissions and energy efficiency targets. ${ }^{67}$ Specifically, European officials have urged U.S. support for an international treaty regulating greenhouse gas emissions after 2012, when the U.N. Kyoto Protocol is set to expire, and for an international market-based carbon emissions credit trading system.

European officials appear encouraged by what they perceive as an increasing U.S. willingness to acknowledge climate change as a problem with serious global ramifications, and to link energy and climate change policy. However, they are reportedly frustrated by U.S. reluctance to commit to binding international emissions and energy efficiency targets. The United States is not party to the Kyoto Protocol, and the Bush Administration reportedly views global regulation to address climate change with skepticism; instead, U.S. officials advocate transatlantic and international cooperation to develop alternative and renewable energy sources and liberalize international energy markets. To this end, the United States and EU used their 2007 summit to launch a series of initiatives jointly promoting technological advances in clean coal and carbon capture and storage, biofuels, energy efficiency, and methane recovery. U.S. officials argue that such technological innovation is proving more effective in reducing emissions than global regulation, and that such regulation may actually impede the economic growth necessary to sustain further technological advances. To support their claims, Bush Administration officials point out that, despite EU participation in the Kyoto Protocol, carbon dioxide emissions increased at a faster rate in the EU than in the United States from 2000-04. During the same period, they add, U.S. economic growth outpaced economic growth in the EU. ${ }^{68}$

Just as EU member states have expressed concern regarding a perceived U.S. reluctance to link transatlantic energy security to pursuit of a global climate change treaty, U.S.

${ }^{65}$ According to BP's Statistical Review, the United States' share of global oil consumption is approximately 43 percent, and gas consumption, 23 percent. The EU accounts for 18 percent of global oil consumption and 19 percent of natural gas usage.

66 See BP Statistical Review, op. cit.

67 "EU-US Summit To See Trade Move but No Climate Deal," EU Observer (26 April 2007); "EU's Climate Change Drive Postponed," European Voice (2 May 2007).

${ }^{68}$ Speech by Kurt Volker, Principal Deputy Assistant Secretary of State for European and Eurasian Affairs, at the German Marshall Fund Berlin, 12 February 2007; available at www.gmfus.org. See also "EU and U.S. Head for Climate Change Clash," European Voice (29 March 2007). 
officials and analysts point to a potential long-term threat to transatlantic relations arising from European dependence on Russian energy and Gazprom's growing influence in large segments of Europe's energy infrastructure. ${ }^{69}$ To this end, the Bush Administration has been supportive of efforts to build pipelines and develop other transportation routes from Central Asia and the Caspian Region to Europe that bypass Russia. In addition, U.S. critics of EU policy toward Russia argue that the EU should strengthen its resolve in requiring Russia to ratify the Energy Charter Treaty and to accept standard open market business practices, competition, and foreign investment in its energy sector. Some Europeans, and particularly Germans, on the other hand, appear reluctant to take concerted action toward Russia that may be viewed as antagonizing a country they view as an essential strategic partner on a variety of important issues beyond energy. ${ }^{70}$

Lastly, transatlantic discussion of energy supply security also includes energy crisis management and infrastructure protection. In this regard, some have called for NATO involvement in energy security issues, including in securing supply sources, distribution routes, and storage facilities. In 2006, Poland circulated a proposal for a so-called "Energy NATO," calling on an increased role for NATO in guaranteeing the protection of member state energy supplies. In a similar vein, in an address at NATO's November 2006 Summit in Riga, Latvia, Senator Lugar proposed the extension of NATO's collective defense clause, Article V, to cases where a member state's energy security is threatened. Other EU member states, notably Germany and France, have greeted such proposals skeptically, preferring to advocate an enhanced EU role in energy security matters.

However, still others assert that NATO's role in energy security could be complementary to the EU's effort to strengthen market forces and interdependence in the international energy sector by offering assistance for the protection of pipelines or shipping lanes during times of political unrest or conflict. NATO Partnership for Peace countries, such as Kazakhstan and Turkmenistan, which are important energy producers, are seeking ways to associate themselves more closely with NATO, in part to diminish Russian influence and in part to develop reliable partners in an unstable region. For some, NATO has the ability to help secure the energy infrastructure of such countries. ${ }^{71}$

69 Keith Smith, "Russian Energy Pressure Fails to Unite Europe."

70 Interviews with German and European officials, January-March 2007.

71 For additional information see Paul Gallis, NATO and Energy Security. 


\section{Bibliography}

Ahearn, Raymond J.. Europe: Rising Economic Nationalism?. Washington, D.C.: Congressional Research Service, 2006.

Archick, Kristin. The European Union: Questions and Answers. Washington, D.C.: Congressional Research Service, 2006.

Bakst, Alex. "Baltic Sea Pipeline: Sweden Afraid of Russian Spooks." Spiegel Online(2006).

Barysch, Katinka, Simon Tilford, and Aurore Wanlin. The Lisbon Scorecard VII - Will Globalization Leave Europe Stranded?. London: Centre for European Reform, 2007.

Drozdiak, William. "Russia: More Awkward, But Still Indispensable." European Affairs 7, no. 1 (2006).

Gallis, Paul. NATO and Energy Security. Vol. 85. Washington, D.C: Congressional Research Service, 2007.

Hamilton, Daniel S., and Joseph P. Quinlan. Deep Integration: How Transatlantic Markets are Leading Globalization. Brussels: Centre for European Policy Studies, 2005.

Luciani, Giacomo. "Security of Supply for Natural Gas Markets." In NDES Working Paper No. 2. Center for European Policy Studies, 2004.

Monaghan, Andrew. "Russia-EU Relations: An Emerging Energy Security Dilemma." Pro et Contra 10, no. 2 (2006).

Nichol, Jim, Steven Woehrel, and Bernard A. Gelb. Russia's Cutoff of Natural Gas to Ukraine: Context and Implications. Washington, D.C.: Congressional Research Service, 2006.

Pirog, Robert. "Russian Oil and Gas Challenges." Connections: The Quarterly Journal 6, no. 3 (2007): 82-99.

Smith, Keith. "Russian Energy Pressure Fails to Unite Europe." Eurofocus 13, no. 1 (2007).

Socor, Vladimir. "Gazprom Broadens, Deepens Inroads Into European Union's Internal Markets, Transport Systems." Eurasia Daily Monitor (2006).

Van Gennip, Jos. Energy Security, NATO Parliamentary Assembly paper., 2006.

Yergin, Daniel. "Ensuring Energy Security." Foreign Affairs (2006).

Yergin, Daniel. "What Does Energy Security Really Mean?" Wall Street Journal (2006). 